\title{
Parametre výkonu v závislosti na šírke úchopu v benčprese
}

\section{Parameters of mean power related to width of grip in bench press}

\author{
Vanderka Marián, Kojnok Martin, Longová Katarína \\ Fakulta telesnej výchovy a športu, Univerzita Komenského v Bratislave, Slovenská republika
}

\begin{abstract}
Abstrakt
Objektivizácia diagnostiky silovo-rýchlostných schopností je téma vysoko aktuálna. Väčšina štúdii bola doposial' zameraná na aktivitu svalových skupín, pomocou elektromyografie, v tlaku v l’ahu na lavičke (benčprese) pri rôznych spôsoboch vykonania. Hlavným ciel’om výskumu bolo porovnanie vybraných parametrov sily pri rôznych širkach úchopu v tlaku v l’ahu na vodorovnej lavičke. Hodnotili sme najvyšši priemerný výkon v celej a v akceleračnej časti koncentrickej fázy pohybu v stupňovanej diagnostickej sérii. Výsledky potvrdili hypotézy, pretože najvy̌šsi priemerný výkon vo wattoch v celej koncentrickej fáze pohybu bol

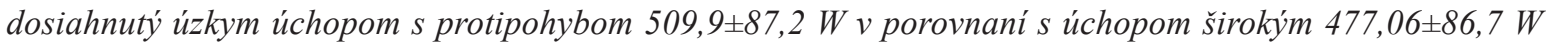
$(p<0,01)$. V akceleračnej časti koncentrickej fázy pohybu bol najvyšši priemerný výkon dosiahnutý úzkym

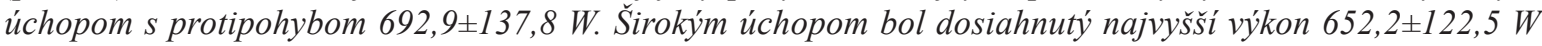
$(p<0,05)$. Odporúčame využivat' úzky úchop v benčprese ako špeciálny prostriedok rozvoja silových schopností. Hlavne v športoch, ktorých biomechanická štruktúra pohybu je podobná ako napr. boby, hádzaná, karate, box a iné.
\end{abstract}

\begin{abstract}
The objectification of strength speed abilities diagnostic is very important in the field of conditioning. The studies are mostly concentrated on activity of muscle groups, by EMG, in various ways to do bench press. The main aim of research was compare selected parameters of strength in two basic grip wide of press on horizontal bench. We measured the maximal mean power in total and in acceleration part of concentric phase of movement in increased diagnostic series in bench press. The results confirmed our the hypothesis, the peak mean power in total concentric phase was achieved by narrow grip with counter movement $509,9 \pm 87,2 \mathrm{~W}$ and with wide grip 477,06 $\pm 86,7 \mathrm{~W}(\mathrm{p}<0,01)$. In acceleration part of concentric phase was the peak of mean power achieved in a narrow grip with counter movement $692,9 \pm 137,8 \mathrm{~W}$, although in wide grip only $652,2 \pm 122,5 \mathrm{~W}(p<0,05)$. We recommend to use narrow grip as a mean os special strength development especially in sports where kinematics of movement are similar for example bobsleigh, handball, karate, box, etc.
\end{abstract}

Kl'účové slová: tlak na lavičke, benčpres, výkon, protipohyb, širka úchopu

Keywords: bench press, power, countermovement, grip wide

\section{ÚVOD}

Š́rka úchopu vplýva jednak na aktivitu rôznych svalových skupín, ktoré sa zapájajú pri jednotlivých spôsoboch vykonania Barnett et al. (1995). Pri vykonaní tlaku v l'ahu na vodorovnej lavičke úzkym úchopom (100 \% BAV) zistili pomocou EMG vyššiu aktivitu deltového svalu (kl’účna čast'), vel'kého prsného svalu (kl'účna čast') a trojhlavého svalu ramena. Pri širokom úchope (200 \% BAV) to bolo naopak, vyššiu aktivitu vyvolal vel'ký prsný sval (mostíkovo-rebrová čast') a najširší sval chrbta. Najvyššiu prekonanú hmotnost' v priemere namerali pri širokom držaní.

Lehman (2005) skúmal vplyv šírky úchopu na aktivitu jednotlivých svalov meranú pomocou EMG. Zaznamenal väčšiu aktivitu vel'kého prsného svalu pri širšom úchope, pričom pri užších úchopoch sa aktivita prenášala na trojhlavý sval ramena.

Smith a Griswold (1998) porovnávali vykonanie tlaku v l’ahu na lavičke úzkym, stredným a širokým úchopom. Ich výskumu sa zúčastnilo 12 mužov a 12 žien, každý z nich vykonával tlak v l’ahu na lavičke všetkými tromi spôsobmi. Najvyššie hodnoty rýchlosti a zrýchlenia namerali pri úzkom úchope a boli významné na 1\% hladine štatistickej významnosti oproti d’alším dvom spôsobom vykonania. 
Rae et al. (2012) skúmali zrýchlenie v ramennom kíbe pri úzkom a širokom spôsobe vykonania tlaku v l'ahu na vodorovnej lavičke. Zistili, že maximálne zrýchlenie v ramennom kíbe bolo pri úzkom úchope 35 stupňov/sekundu a širokom úchope 20 stupňov/sekundu. Ďalej sledovali priemerné zrýchlenie, ktoré bolo pri úzkom úchope 30 stupňov/sekundu a pri širokom úchope 20 stupňov/sekundu.

Wilson et al. (1991) sa zaoberali využívaním elastických vlastností svalov a šliach pri tlaku v l’ahu. Najväčší odpor bol prekonaný pri narazení činky o hrudník. Druhý bol klasický spôsob vykonania, pri ktorom prekonaný odpor bol o 14,5\% menší ako pri narazení činky o hrudník. Najnižšie hodnoty namerali vykonaní s krátkym zastavením v spodnej polohe a pri dlhšom zastavení.

Pomerom rôznych svalových vlákien zastúpených v l'udských svaloch sa zaoberal aj Colling (2012), ktorý uvádza, že v trojhlavom svale ramena tj. musculus triceps brachi sa nachádza $67,4 \%$ rýchlych svalových vlákien. Naopak vo vel'kom prsnom svale - hornej, klúčnej časti tj. musculus pectoralis major sa nachádza 57,7 \% rýchlych svalových vlákien, čo je o 9,7 \% menej a môže to byt' jeden s faktorov, ktorý bude v konečnom dôsledku ovplyvňovat' priemerný výkon, ale aj zrýchlenie v diagnostickej sérii v tlaku v l’ahu na vodorovnej lavičke. Autor polemizuje nad problematikou pomeru rôznych svalových vlákien zastúpených v l’udských svaloch. Popisuje, že štúdie vzájomného pomeru svalových vlákien v l'udskom tele sú spojené z mnohými metodologickými problémami. V mnohých štúdiách sú hodnoty uvádzané len orientačné. Jedným s problémov je neopakovatel'nost' odberu z toho istého miesta a na inom mieste môže byt' vzorka s inými pomermi, druhým problémom je malý počet sledovaných subjektov.

Ak však vychádzame z predpokladu, že v triceps brachii sa nachádza viac rýchlych svalových vlákien ako $\mathrm{v}$ pectoralis major a triceps brachii je viac aktívny pri úzkom spôsobe prevedenia, možno pri úzkom úchope predpokladat' vyššie hodnoty výkonu.

\section{CIEL}

Objektivizovat' diagnostiku silových schopností prostredníctvom porovnania vybraných parametrov sily (priemerný výkon $\mathrm{v}$ celej a $\mathrm{v}$ akceleračnej časti koncentrickej fázy pohybu v diagnostickej sérii) pri rôznych šírkach úchopu jedného z najpopulárnejších cvičení tlak v l'ahu na vodorovnej lavičke (benčpres).

\section{HYPOTÉZY}

H1 Predpokladáme významne vyššie hodnoty najvyššieho priemerného výkonu v aktívnej fáze pohybu pri cvičení tlak v l'ahu na vodorovnej lavičke s protipohybom ako bez protipohybu.

H2 Predpokladáme najvyššie hodnoty priemerného výkonu v celej a aj v akceleračnej časti koncentrickej fázy pohybu pri tlaku v l’ahu na vodorovnej lavičke s protipohybom pri úzkom úchope činky.

\section{METODIKA}

Išlo o jednoskupinový prierezový ex-post facto typ výskumu. Súbor tvorilo 25 študentov FTVŠ U

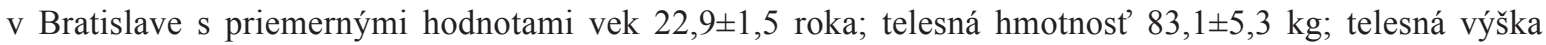
$182,5 \pm 5,4 \mathrm{~cm}$. Všetci probandi zúčastnení na našom testovaní vykonávajú pohybovú aktivitu aj vo svojom vol’nom čase. Probandi boli vybraný na testovanie zámerným výberom na základe ich dobrovol’nosti a dostupnosti.

Údaje sme získavali meraním jednotlivých probandov pomocou Fitrodyne Premium (obr. 1). Toto zariadenie registruje polohu a rýchlost’ pohybu pri známej hmotnosti závažia, ktorého výsledky sú transformované do počítača prepojeného cez interface. Parametre silových schopností sa určujú nepriamo a to z rýchlosti pohybu a hmotnosti závažia. Pri známej hmotnosti činky stačí určit zrýchlenie a z týchto dvoch veličín pomocou Druhého Newtonovho zákona $(F=m$. a) vypočítat' okamžitú silu. Pri pohybe smerom nahor treba k registrovanému zrýchleniu pripočítat' aj hodnotu gravitačnej konštanty g, takže vzorec pre výpočet aktuálnej sily bude mat' formu $(\mathrm{F}=\mathrm{m}$. $(\mathrm{g}+\mathrm{a}))$. Pri známej sile a rýchlosti sa dá vypočítat' výkon $(\mathrm{P}=\mathrm{F} . \mathrm{v})$, ktorý je možné získat' aj z výpočtov svalovej práce $(\mathrm{W}=\mathrm{F}$. s) vykonanej za časovú jednotku $(\mathrm{P}=\mathrm{W} / \mathrm{t})$. Výkon je vyjadrený vo wattoch (W) (Schickhofer, 2003). 


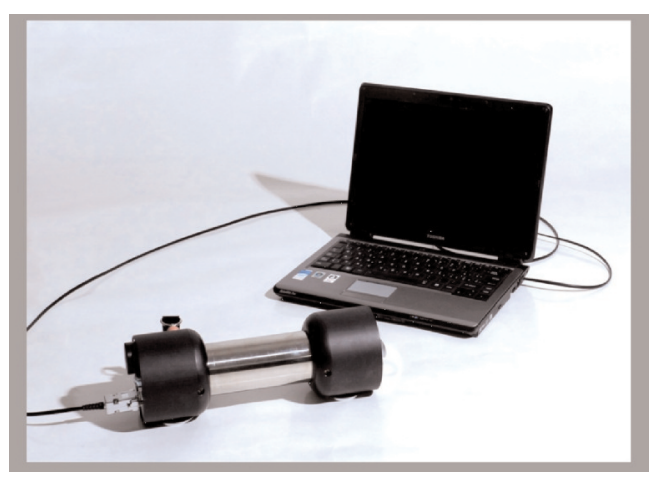

Technicky sa systém skladá z dvoch komponentov, a to zo senzorovej a elektronickej jednotky, umiestnených v malej tube. Rýchlostný senzor je spojený s rotačným ret’azovým kotúčom a pripojený k závažiu prostredníctvom úzkej nylonovej struny, na ktorej konci je krúžok so suchým zipsom. Spätný chod kotúča vykonáva strunový mechanizmus s odporom menším ako 2 N. Nylonová struna môže byt' natiahnutá do vzdialenosti maximálne 2,5 metra. Senzorová jednotka obsahuje presný analogický rýchlostný senzor a senzor s infračerveným impulzom s rozlíšením 2 milimetre. Pri t’ahaní ret’aze mimo kotúč (alebo pri vracaní spat') sa táto rotácia a rýchlost' presne meria. Elektronická jednotka obsahuje signálnu čast', 12 bitový AD konvertor a interface pre komunikáciu, ktorá je kompatibilná s počítačom pomocou COM 1 (FITROdyne Premium, 2011).

Jednotlivé spôsoby realizácie tlaku na lavičke sme testovali minimálne s 48 hodinovými prestávkami pre objektivizáciu nameraných výsledkov. Probandi boli testovaní v diagnostickej sérii, pred ktorou bolo vždy zaradené rozcvičenie s $20 \mathrm{~kg}$ olympijskou činkou. Diagnostická séria bola realizovaná pre každý spôsob samostatne od $20 \mathrm{~kg}$ dve hmotnosti nad výkonové maximum s pridávaním 10 kg doplnkovej zát’aže. Pred každou diagnostickom sériou sme probandom odmerali rozsah pohybu pri danej technike prevedenia. Testovaní mali 1 pokus na realizáciu jednotlivých prevedení techniky pri každej hmotnosti. Probandi boli inštruovaní vykonávat' každý pokus maximálnym úsilím v koncentrickej fáze pohybu. Medzi pokusmi mali testovaní pauzu minimálne 2 minúty. Sledovali sme parametre: priemerný výkon v celej koncentrickej fáze ale aj v jej akceleračnej časti pri každej hmotnosti v diagnostickej sérii.

Tlak na vodorovnej lavičke vykonávali probandi s olympijskou činkou. L'ahli si na lavičku tak, aby mali činku, ktorá bola na stojanoch, nad hlavou. Nohy mali ohnuté v kolennom kíbe, chodidlami sa museli dotýkat' zeme a sedacie svaly, lopatky a hlava museli byt' v neustálom kontakte s lavičkou, túto polohu zachovali aj pri realizácii meraných pokusov.

V prvom meraní bola diagnostická séria (DS) vykonávaná tak, že probandi držali činku v rukách na šírky $100 \%$ z ich vlastnej biakromiálnej vzdialenosti (BAV), čo je šírka ramien - priama vzdialenost' medzi pravým a l’avým bodom nadplecku, čo možno charakteriziovat' ako úzky úchop (NG) (obr. 3) a testovanie vykonávali bez protipohybu z pokojového stavu, od hrudníka (obr. 2 dolná čast').

V druhej DS bola šírka úchopu daná vzdialenost'ou rúk v upažení s $90^{\circ}$ pokrčením v lakt’ovom kíbe, široký úchop (WG) (obr. 4) a testovanie bolo taktiež vykonávané bez protipohybu od hrudníka (obr. 2 dolná čast').

Obr. 2 Schematické tlaku v l'ahu na vodorovnej lavičke (benčpres) s protipohybom (PR) a bez protipohybu (ST)

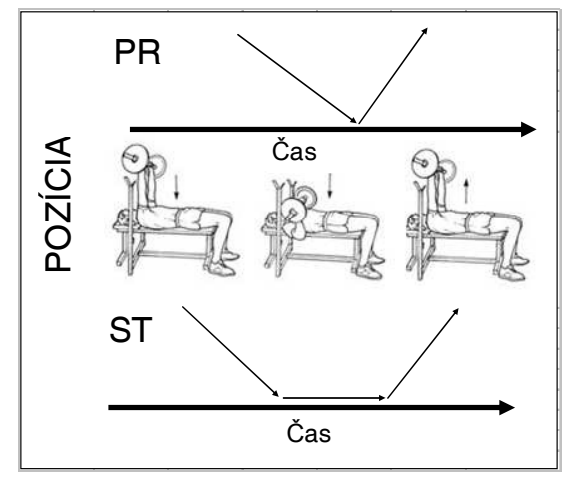


Obr. 3 Úzky úchop $(N G)$

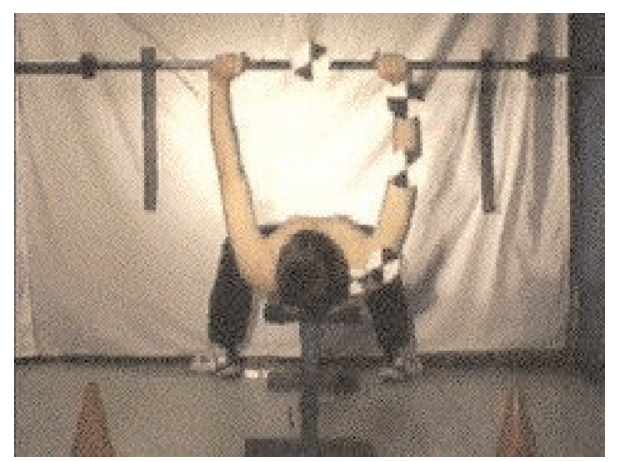

Obr. 4 Široký úchop $(W G)$

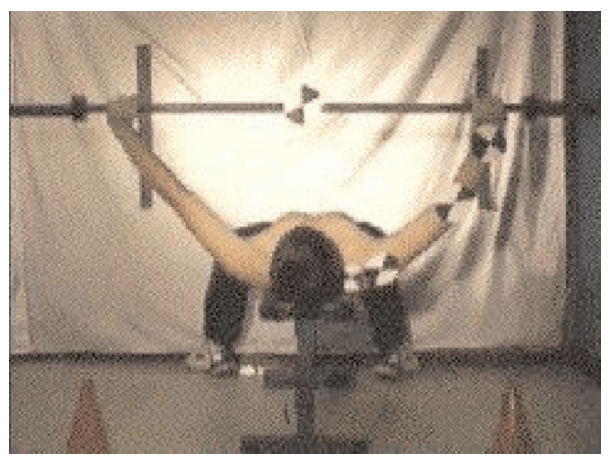

V tretej DS bolo testovanie vykonávané širokým úchopom (obr. 4) s protipohybom (obr. 2 horná čast'), excentrickú fázu mali probandi vykonávat' podl'a svojho uváženia, počas tohto pohybu sa nadychovali až kým sa činka nedotkla hrudníka, potom nasledovala koncentrická fáza pohybu, ktorá sa vykonávala maximálnym úsilím z výdychom až do začiatočnej polohy. $V$ dolnej polohe pohybu sa nezastavovalo. Za testovaným vždy stála osoba, ktorá pomáhala pri návrate činky do stojanov, avšak svojou pomocou test neovplyvňovala. V štvrtej DS bolo testovanie vykonávané taktiež s protipohybom (obr. 2 horná čast'), ale úzkym úchopom činky (obr. 3). Pri štatistickom vyhodnocovaní sme použili na porovnanie významnosti rozdielov parametrický nepárový t-test.

\section{VÝSLEDKY a DISKUSIA}

Priemerný výkon v celej koncentrickej fáze pohybu v diagnostickej sérii (obr.5) úzkym úchopom s protipohybom 509,9 $\pm 87,2 \mathrm{~W}$ a širokým úchopom s protipohybom 477,06 $\pm 86,7 \mathrm{~W}$, rozdiel 32,8 $\pm 9,7 \mathrm{~W}$, čo je 6,4 \% ( $\mathrm{t}=4,48$; $\mathrm{p}<0,01)$. Úzkym úchopom bez protipohybu bol priemerný výkon v diagnostickej sérii $339,0 \pm 83,9 \mathrm{~W}$ a širokým úchop bez protipohybu bol 326,2 $\pm 76,0 \mathrm{~W}$, rozdiel $12,8 \pm 35,4 \mathrm{~W}$, čo je $3,78 \%(\mathrm{t}=0,82 ; \mathrm{p}=\mathrm{n}$.s.).

Domnievame sa, že je to spôsobené dlhšou dráhou pohybu, následným dlhším pôsobením pákových mechanizmov a vyššími hodnotami rýchlosti pri realizácii pohybu s užším úchopom, ktoré vo svojej štúdii namerali aj Smith - Griswold (1998). Priemerný výkon v tlaku v l'ahu na vodorovnej lavičke úzkym úchopom môže byt' ovplyvnený aj vyššími hodnotami maximálnej akcelerácie a taktiež vyšším počtom rýchlych svalových vlákien v triceps brachii, ktoré sa môžu kontrahovat' rýchlejšie ako pomalé vlákna. Pri úzkom úchope je možné uskladnit' väčšie množstvo elastickej energie a následne ju aj využit', čo potvrdzuje aj Wilson et. al. (1991).

Porovnali sme aj priemerné hodnoty najvyšších priemenrých výkonov s prtopohybom a bez proipohybu spoločne pri oboch šírkach úchopu. Pri vykonaní s protipohybom (sPP) to bolo v priemere 493,5 $\pm 87,0 \mathrm{~W}$ a bez protipohybu (bez PP) 332,6 $\pm 80,0 \mathrm{~W}$, čo je 35,5\% rozdiel ( $\mathrm{t}=14,39 ; \mathrm{p}<0,01)$, čím sme potvrdili náš predpoklad. Podobne aj Tihanyi (2002) potvrdil vyššie výkonny pri cvičeniach s protipohybom. Uvádza, že pri protipohybe sa aktivizujú reflexné mechanizmy a najmä v sériovom elastickom komponente sa uskladňuje potenciálna energia pružnosti, ktorú možno v koncentrickej fáze pohybu pripočítat' k samotnej kontraktilnej svalovej sile, a tak dochádza k produkovaniu vyšších výkonov.

Schmidtbleicher (2004) uvádza, že trvanie a vel'kost' natiahnutia pred nasledujúcou koncentrickou kontrakciou nesmie byt' dlhšie ako $150 \mathrm{~ms}$ resp. 3-4 \% z možného maximálneho natiahnutia, inak je využívanie reflexnoelastických vlastností problematické. To nie je v súlade s našimi sledovaniami, pretože len samotná excentrická kontrakcia pri výkonovom maxime trvá 0,8 až 1 sekundu. Vysvetlenie možno nájst' v zvýšení napätia v kontraktilnom komponente na konci protiphybu, ktoré netrvá dlho a nie je po vel'kej dráhe, a tak je pravdepodobne možné aktivovat' vyššie uvedené reflexno-elastické mechanizmy. 
Obr. 5 Najvyššie priemerné výkony (priem \pm sd) v celej koncentrickej fáze pohybu v stupňovanej diagnostickej sérii s protipohybom (s PP) a bez protipohybu (bez PP) so širokým a úzkym úchopom v benčprese

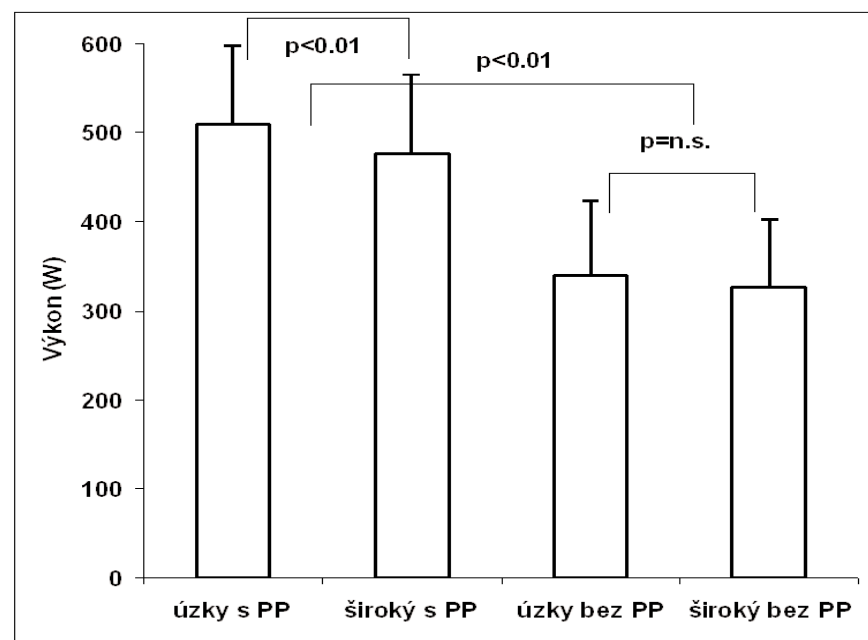

Hmotnost' pri najvyššom priemernom výkone v celej časti koncentrickej fázy pohybu (obr. 6) pri úzkom spôsobe s protipohybom bola $51,6 \pm 10,6 \mathrm{~kg}$ a pri širokom úchope s protipohybom $54 \pm 11,1 \mathrm{~kg}$, rozdiel 2,4 $\pm 3,32 \mathrm{~kg}$, čo je $4,44 \%$ ( $\mathrm{t}=1,81 ; \mathrm{p}=\mathrm{n}$.s.). Úzkym úchopom bez protipohybu pri maximálnom priemernom výkone $\mathrm{v}$ celej časti koncentrickej fázy pohybu v diagnostickej sérii boli hmotnosti činky v priemere $49,2 \pm 11,5 \mathrm{~kg}$ a širokým úchopom bez protipohybu 48,8 $\pm 10,9 \mathrm{~kg}$, rozdiel $0,4 \pm 3,65 \mathrm{~kg}$, čo je $0,81 \%$ ( $\mathrm{t}=0,14$; $\mathrm{p}=\mathrm{n} . \mathrm{s}$.).

$\mathrm{Na}$ základe toho, že vel'ký prsný sval (m. pectoralis major) disponuje väčšou plochou prierezu a následnou vyššou maximálnou silou v porovnaní s trojhlavým svalom ramena (m. triceps brachii) možno predpokladat', že hmotnosti pri dosiahnutí výkonového maxima budú vyššie pri širokom úchope v porovnaní z úzkym. Vyššie hodnoty hmotností pri širokom úchope s protipohybom však neboli štatisticky významné, takže ich môžeme považovat' za náhodné. Rozdiel v hmotnostiach pri ktorých bol dosahovaní najvyšší priemerný výkon v celej časti koncentrickej fázy pohybu pri širokom úchope s protipohybom a bez protipohybu je síce väčší ako pri úzkom úchope s protipohybom a bez protipohybu, ale tiež nie štatisticky významný. Môže to byt' spôsobené tým, že väčšina testovaných vykonáva tlak v l'ahu na lavičke širokým spôsobom s protipohybom a tento spôsob vykonania má po technickej stránke lepšie zvládnutý ako široký spôsob bez protipohybu a naopak vykonania úzkym úchopom realizujú zriedkavejšie.

Obr. 6 Hmotnosti činky (priem \pm sd) pri výkonovom maxime - najvyššom priemernom výkone v celej koncentrickej fáze pohybu v stupňovanej diagnostickej sérii s protipohybom (s PP) a bez protipohybu (bez PP) so širokým a úzkym úchopom v benčprese

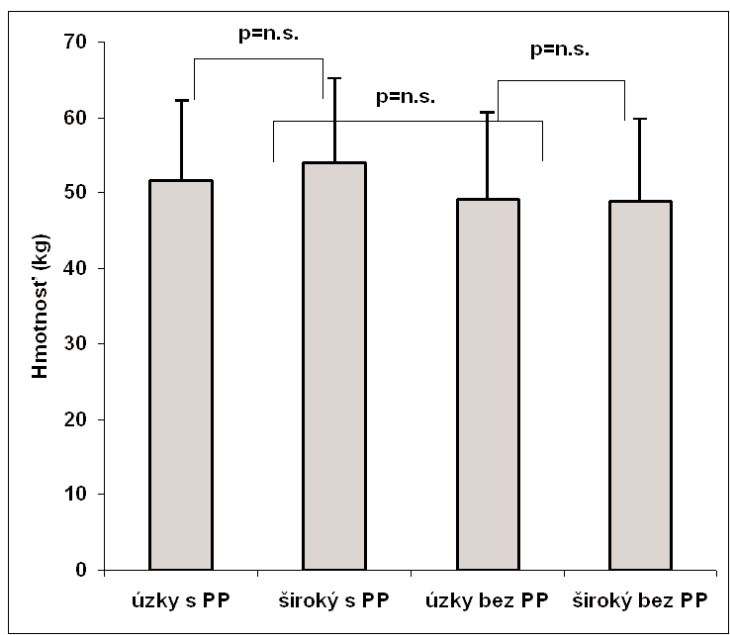


Ked’že priemerná sila a priemerný výkon môžu byt’ skreslené negatívnymi hodnotami v prípade sa vyskytujúcej brzdiacej fáze $\mathrm{v}$ závere aktívneho pohybu, možno alternatívne (pre lepšiu objektivizáciu silovo-rýchlostných schopností) používat' priemerné hodnoty iba vo fáze s pozitívnou silou, resp. výkonom (Schickhofer, 2003). Môžeme hovori o akceleračnej časti v rámci koncentrickej fázy pohybu.

Najvyšší priemerný výkon vo wattoch v akceleračnej časti koncentrickej fázy pohybu v diagnostickej sérii

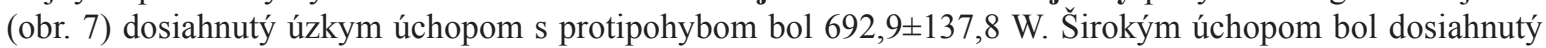

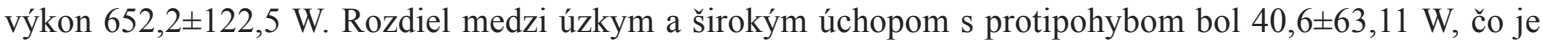
$5,87 \%(t=2,27 ; p<0,05)$. Úzkym úchopom bez protipohybu bol najvyšší priemerný výkon v akceleračnej časti

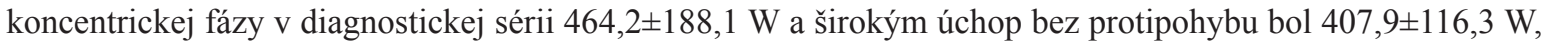
rozdiel $56,3 \pm 147,7 \mathrm{~W}$, čo je $12,14 \%$ ( $\mathrm{t}=1,61$; $\mathrm{p}=$ n.s. $)$.

Výsledky potvrdzujú náš predpoklad, že najvyšší priemerný výkon vo wattoch v akceleračnej časti koncentrickej fáze pohybu bude najvyšší pri úzkom úchope činky s protipohybom. Vyššie hodnoty sú pravdepodobne spôsobené dlhšou dráhou pohybu pri úzkom úchope, s možnost'ou dlhšieho pôsobenia na činku a možnost'ou väčšieho zrýchlenia pri tomto spôsobe vykonania. Podobne aj Rae et. al. (1998) zistili vyššie hodnoty priemernej akcelerácie v ramennom kíbe (o $10^{\circ}$.s-1) pri úzkom úchope oproti vykonaniu širokým úchopom. Pri úzkom spôsobe s protipohybom, kde sa viac aktivizuje trojhlavý sval ramena, sa môže viac elastickej energie uskladnit' v dlhšej šl'ache, ktorou sa triceps brachii upína na kost'. Naopak pri vykonaní bez protipohybu sa táto energia nezíska a potom ani následne nemôže využit', čo sa odzrkadl'uje aj na hodnotách výkonu.

Porovnali sme aj priemerné hodnoty najvyšších priemenrých výkonov v akceleračnej časti koncentrickej fázy s prtopohybom a bez proipohybu spoločne pri oboch šírkach úchopu. Pri vykonaní s protipohybom (sPP) to bolo v priemere $672,6 \pm 130,2 \mathrm{~W}$ a bez protipohybu (bez PP) 436,1 $152,2 \mathrm{~W}$, čo je $35,2 \%$ rozdiel ( $\mathrm{t}=9,89$; $\mathrm{p}<0,01)$, čím sme potvrdili náš predpoklad.

Obr. 7 Najvyššie priemerné výkony (priem \pm sd) v akceleračnej časti koncentrickej fázy pohybu v stupňovanej diagnostickej sérii s protipohybom (s PP) a bez protipohybu (bez PP) so širokým a úzkym úchopom v benčprese

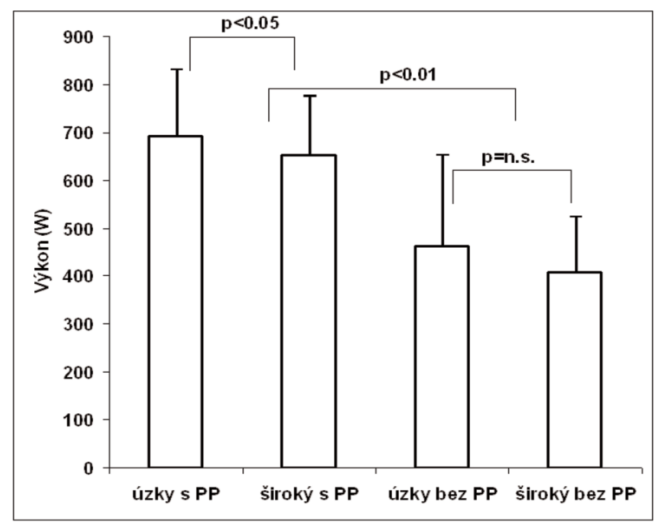

Hmotnosti činky s ktorými sa dosahoval najvy̌šsí priemerný výkon v akceleračnej časti koncentrickej fázy pohybu (obr. 8) pri úzkom spôsobe vykonania s protipohybom boli $40 \pm 10,4 \mathrm{~kg}$ a pri širokom úchope s protipohybom $38,4 \pm 12,1 \mathrm{~kg}$, rozdiel $1,6 \pm 6,2 \mathrm{~kg}$, čo je $4 \%$ (t=0,61; p=n.s.). Úzkym úchopom bez protipohybu boli hodnoty priemerných hmotností s ktorými sa dosahoval najvyšší priemerný výkon v akceleračnej časti koncentrickej fázy pohybu v diagnostickej sérii $46,4 \pm 12,8 \mathrm{~kg}$ a širokým úchopom bez protipohybu 46,4 $\pm 12,5 \mathrm{~kg}$, rozdiel sme $\mathrm{v}$ tomto prípade nenašli.

Pri oboch spôsoboch vykonania (NG a WG) s protipohybom boli hmotnosti pri ktorých sa dosahoval najvyšší priemerný výkon $\mathrm{v}$ akceleračnej fáze nižšie oproti vykonaniam bez protipohybu. S protipohybom (sPP) to bolo

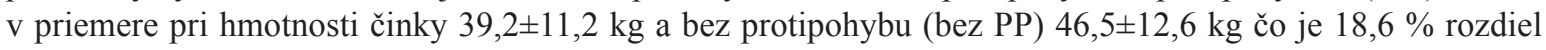
$(t=3,98 ; p<0,01)$ Pri cvičení s protipohybom sa viac využívajú reflexno-elastické vlastnosti svalov a šliach, naproti tomu bez protipohybu dochádza $\mathrm{k}$ aktivácii väčšieho množstva motorických jednotiek. Vytvára to možnost' generovat' viac sily, čo potvrdili aj Fleck a Kraemer (2004). Na základe týchto informácií možno vysvetlit' aj nami dosiahnuté výsledky, kde najvyššie hodnoty priemerného výkonu v akceleračnej fáze boli pri významne vyšších hodnotách vonkajšieho odporu. 
Obr. 8 Hmotnosti činky (priem \pm sd) pri výkonovom maxime - najvyššom priemernom výkone v akceleračnej časti koncentrickej fázy pohybu v stupňovanej diagnostickej sérii s protipohybom (s PP) a bez protipohybu (bez PP) so širokým a úzkym úchopom v benčprese

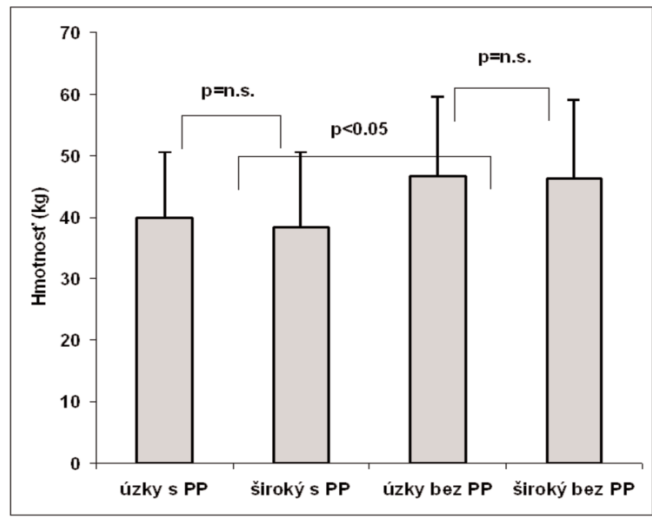

\section{ZÁVERY}

Najvyššie hodnoty priemerného výkonu v celej koncentrickej fáze pohybu sme namerali pri úzkom úchope

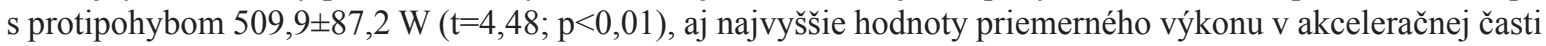
koncentrickej fáze pohybu sme namerali pri úzkom úchope s protipohybom $692,9 \pm 137,8 \mathrm{~W}(\mathrm{t}=2,27 ; \mathrm{p}<0,05)$, čo potvrdzuje naše hypotézy.

Ked’že vyššie hodnoty maximálnej akcelerácie sme namerali pri vykonaní s úzkym úchopom, odporúčame tento typ úchopu využívat' ako špeciálny prostriedok rozvoja silových schopností. Hlavne v športoch, ktorých biomechanická štruktúra pohybu sa podobá tlaku v l’ahu na vodorovnej lavičke s úzkym úchopom ako napríklad boby, vodné pólo, hádzaná, karate alebo box. Využívat' tlak v l'ahu na vodorovnej lavičke so širokým úchopom by sme pre tieto druhy športov odporučili ako všeobecný prostriedok rozvoja silových schopností.

V športovej praxi netreba zabúdat' ani na cvičenia bez protipohybu. Dochádza pri nich k vyššiemu množstvu zapojených motorických jednotiek. Preto ich odporúčame zarad’ovat' najmä na začiatku mezocyklo v zameraných na rozvoj silových schopností. Okrem toho cvičenia bez protipohybu umožňujú lepšiu kontrolu technicky správneho vykonania pohybu.

\section{Literatura}

BARNETT, C., KIPPERS, V., and TURNER, P. 1995. Effects of variation on the bench press exercise on the EMG activity of five shoulder muscles. In Journal of Strength and Conditional Research. 1995, Vol. 9, No. 4, pp. 222-227.

COLling, R. 2012. Fibre Type Distribution in Human Muscles. [citované 28.03.2012]. Dostupné na http://physiotherapy.curtin.edu.au/resources/educational-resources/exphys/97/ fibretypedist.cfm FITROdyne Premium. 2012. FITROdyne Premium. [citované 28.03.2012]. Dostupné na http://www.fitronic.sk/fitrodyne_premium.htm>.

FLECK, S.J., KRAEMER, W.J. 2004. Designing resistance training programs. Human Kinetics, 3rd ed. vydanie, 377 p. ISBN 0-7360-4257-1

LEHMAN, G. J. 2005. The influence of grip width and forearm pronation/supination on upper-body myoelectrical activity during the flat bench press. Journal of Strength and Conditional Research., Vol. 19, No. 3, pp. 587-591.

SMITH, J., GRISWOLD, S. 1998. The effects of grip width on bench press performance using novice lifters. [citované 28.03.2012]. Dostupné na http://www.asbweb.org/ conferences/1990s/1998/239/index.html

RAE, R, PACKARD, D., and EUBANK, CH. 2012. Biomechanical Analysis: Wide vs. Narrow Grip Bench Press. [citované 28.03.2012]. Dostupné na http://www.umich.edu/ mvs330/w98/bench/main.html

SCHICKHOFER, P. 2003. Sila a výkon pri rôznych rýchlostiach svalovej kontrakcie u športovcov vybraných špecializácií. In: Acta facultatis educationis physicae Universitatis Comenianae Publicatio XLIV. Bratislava, 2003. pp. 79-138. ISBN 80-223-1914-7 
STUDIA SPORTIVA 2012/6, č. 2, s. 5-12

SCHMIDTBLEICHER, D. 2004. Jumping exercises for explosive strength development in athletes. 4th International Conference on Strength Training. Serres Greece, Nov. 3-7, p. 10-14.

TIHANYI, J. 2002. Biomechanics of the tendons ligaments. In: 3rd International Conference on Strength Training, November 13 - 17, Budapest, pp.49-53.

WILSON G., ELLIOTT B., and WOOD G. 1991. The effect on performance of imposing a delay during a stretch-shorten cycle movement. Medicine Science in Sport and Exercise, Vol. 23, No. 3, pp. 364-370. 